\title{
COMPARISON OF GROWTH PERFORMANCE OF THREE STRAINS OF CLARIAS GARIEPINUS: HYBRID STRAIN, SELECTIVE BREEDING STRAIN AND WILD STRAIN REARED IN CONCRETE TANKS
}

\author{
Yamikani Willie Ntaila \\ University of Malawi, Chancellor College, Department of Biological Sciences.
}

Cite this article:

Yamikani Willie Ntaila (2021), Comparison of Growth Performance of three Strains of Clarias gariepinus: Hybrid Strain, Selective Breeding Strain and Wild Strain Reared in Concrete Tanks. African Journal of Agriculture and Food Science 4(4), 1-10. DOI: 10.52589/AJAFSVCD3Q075.

\section{Manuscript History \\ Received: 24 Aug 2021 \\ Accepted: 13 Sept 2021 \\ Published: 3 Oct 2021}

Copyright $\odot 2020$ The Author(s). This is an Open Access article distributed under the terms of Creative Commons AttributionNonCommercial-NoDerivatives 4.0 International (CC BY-NC-ND 4.0 ), which permits anyone to share, use, reproduce and redistribute in any medium, provided the original author and source are credited.
ABSTRACT: A comparative study was conducted to investigate the growth performance of three strains of Clarias gariepinus reared in concrete tanks. The experiment was carried out for the period of three weeks. Three strains of Clarias gariepinus which were compared were hybrid strain, selective breeding strain and the pure/wild strain. The experimental fish were randomly assigned to three experimental groups. Each treatment was therefore replicated three times with 60 fry per replicate in concrete tanks. At harvest there was no significant difference among Hybrid strain, Selective breeding strain and wild strain $(P>0.05)$ in fish' final body weight $(1.83 \pm 0.11,1.178 \pm 0.46$ and $1.739 \pm 0.42)$. The $S G R$ for hybrid strain, selective breeding strain and wild strains were $12.93 \pm 0.23,4.53 \pm 0.22$ and $12.81 \pm 0.26$. The survival rate for hybrid strain, selective breeding strain and pure strain $70 \%, 80 \%$ and $66.66 \%$ respectively. The was no significant difference $(p>0.05)$ in FCR $(2.12 \pm 0.01,2.12 \pm 0.03$ and $2.11 \pm 0.01)$ for hybrid strain, selective breeding strain and wild strain respectively. Though the difference was not that significant the pure Clarias gariepinus had the lower FCR as compared to the others. Therefore, this study recommends that hybrid Clarias gariepinus has a good performance as compared to the selective breeding strain and the wild Clarias gariepinus.

KEYWORDS: Aquaculture, Physio-Chemical Parameters, Clarias gariepinus 


\section{INTRODUCTION}

Aquaculture in Malawi is reported to have begun in 1906 when the fish species called trout was first introduced in the country. Aquaculture in Malawi comprises of two sub-sectors, namely a long established 'low input-low output' rural aquaculture, and a nascent commercial sector, which ensures the bulk of production. (Breuil et al, 2014). The development of rural aquaculture was supported with the establishment of the Domasi Experimental Fish Farm in 1957 for the breeding and distribution of Tilapia rendalli and Oreochromis shiranus. Commercial aquaculture started in 2004 when two large scale production units were established (Litvinoff, 2009). Aquaculture being one of the key agricultural activities, has potential to contribute to food security and poverty reduction goal by supplementing dwindling capture fisheries that are being exploited beyond their maximum sustainable yields (GoM,2016).

The fish species that are cultured in Malawi include the main species currently farmed in both smallholder and commercial aquaculture operations in Malawi which include the three tilapia species namely Tilapia rendalli, Oreochromis shiranus, $O$. Karongae and the catfish Clarias gariepinus. The three tilapia species account for $93 \%$ of the production, catfish for $5 \%$, and exotic species such as common carp, black bass (Micropterus sp.) and trout 2\% (Russell A et al, 2008). The use of exotic species remains restricted in Malawi for the reason that its introduction may negatively affect the local biota (FAO, 2005). Clarias gariepinus is reported to be the second most important freshwater fish after tilapia (Ponzoni, \&. Nguyen, 2008). The commonly cultured fish, tilapia species, have been blamed for slow growth largely because of its precocious breeding habits (Ponzoni, \&. Nguyen, 2008). Fish farmers prefer selecting $C$. gariepinus for farming due to its fast growth and size which is closely associated with the sale price (Andrew et al. 2003).

The main focus is to screen fast-growing indigenous species for aquaculture. Catfish has been identified as a promising fish for aquaculture because of its rapid growth rate. According to Ponzoni, \&. Nguyen (2008) there are about five catfish species found in Malawi which include, Clarias gariepinus, Clarias liocephalus, Clarias ngamensis, Clarias stappersii and Clarias theodore, of which Clarias gariepinus is the most popular catfish species. In addition to this there is also another air-breathing cat fish called Bathyclarias gigas which is also known as Bathyclarias nyansesis. Bathyclarias gigas is an air breathing catfish that is endemic to Malawi. Since the farming of catfish species in Malawi is preferred by many farmers due its fast growth and size, the nation is focusing on the development of catfish for aquaculture potential (Chirwa, 2008). Thus, the focus for Malawi is to determine the catfish species that is promising for aquaculture because of its rapid growth rate. Therefore, the aim of this study is to compare the growth performance of the three Clarias gariepinus: species namely Hybrid strain, Selective breeding strain and wild/pure strain reared in the concrete tanks.

\section{MATERIALS AND METHODS}

\section{Experimental Design}

The study comprised of the experiments which were conducted at the National Aquaculture Centre. The fry used in the research study experiments belong to the air breathing catfish species found in Malawi. Three strains of Clarias gariepinus were used. The fry was obtained 
from the hatching complex of the National aquaculture Centre from the induced spawns of the three $C$. Gariepinus brood stocks. The study used three treatments of Clarias gariepinus namely pure Clarias gariepinus, Selective breeding strain and the hybrid strain. Each strain was stalked into the separate tank at a stalking density of 60 fry $/ \mathrm{m}^{3}$ each treatment was triplicated such that there was a total of nine concrete tanks. Physiochemical properties of water such as, salinity, $\mathrm{pH}$, dissolved oxygen, temperature was monitored every week. The study was conducted for six weeks.

The measurements were carried out at the start of the experiment to determine the initial mean standard length, and wet weight of the fry. Every week $17 \%$ of the fish in each tank was sampled using the scoping hand net. Fish body wet weight was measured using an electrical weighing balance. After all measurements, the fish was revived in fresh water and then returned to the tank. Water quality parameters were checked every week to ensure the survival of the fish. The water quality parameters that were checked included dissolved oxygen (DO), $\mathrm{pH}$, and temperature.

\section{Statistical Analysis}

The data was analysed using the Statical package for social sciences. The data for the final average weight, weight gain, SGR, FCR and survival rate were analysed using analysis of variance (one-way ANOVA) to determine the significant difference among means. The analysis was set at an alpha level of 0.005 .

\section{RESULTS}

The results for the growth performance assessment of the tree strains of the Clarias gariepinus namely hybrid strain, selective breeding strain and the pure Clarias gariepinus were as follows

Table 1: Growth performance of Clarias gariepinus strains reared in concrete tanks

\begin{tabular}{llll}
\hline Parameters & Hybrid strain & selected breed & Wild strain \\
\hline Initial number stocked & 60 & 60 & 60 \\
\hline Final stock density & 42 & 48 & 40 \\
\hline SR $(\%)$ & 70 & 80 & 66.66 \\
\hline IABW & $0.008 \pm 0.01$ & $0.004 \pm 0.00$ & $0.008 \pm 0.01$ \\
\hline FABW & $1.83 \pm 0.11$ & $1.178 \pm 0.46$ & $1.739 \pm 0.42$ \\
\hline ABWG & $1.822 \pm 0.36$ & $1.174 \pm 0.05$ & $1.731 \pm 0.17$ \\
\hline ADWG & $0.043 \pm 0.008$ & $0.028 \pm 0.001$ & $0.042 \pm 0.001$ \\
\hline FGR & $12.93 \pm 0.23$ & $4.53 \pm 0.22$ & $12.81 \pm 0.26$ \\
\hline FCR & $2.12 \pm 0.01$ & $2.12 \pm 0.03$ & $2.11 \pm 0.01$
\end{tabular}

SR: Survival rate, IABW: Initial Average body weight, FABW: Final Average body weight, ABWG: Average Body Weight gain, ADWG: Average Daily Weight Gain, SGR: Specific growth rate FCR: Feed conversion ratio. 
The table 1 shows the data of the growth performance in terms of weight of the three stains of Clarias gariepinus. The data shows that the Final mean body weight for hybrid, selective breed and pure Clarias gariepinus were $1.83 \pm 0.11 \mathrm{~g}, 1.178 \pm 0.46 \mathrm{~g}$ and $1.739 \pm 0.42 \mathrm{~g}$ respectively. The average body weight gained by the catfish were $1.822 \pm 0.36 \mathrm{~g}$ (hybrid), $1.174 \pm 0.05 \mathrm{~g}$ (selective breed) and $1.731 \pm 0.17 \mathrm{~g}$ (pure Clarias gariepinus) while the Average daily weight gain for hybrid, selective breed and pure Clarias gariepinus were $0.043 \pm 0.008 \mathrm{~g}, 0.028 \pm 0.001 \mathrm{~g}$ and $0.042 \pm 0.001 \mathrm{~g}$ respectively. The hybrid strain had high specific growth rate as compared to the other two strains. It was followed by the pure Clarias gariepinus with the selective breeding strain being the last.

\section{Comparison of the changes in mean weight of the three strains of Clarias gariepinus.}

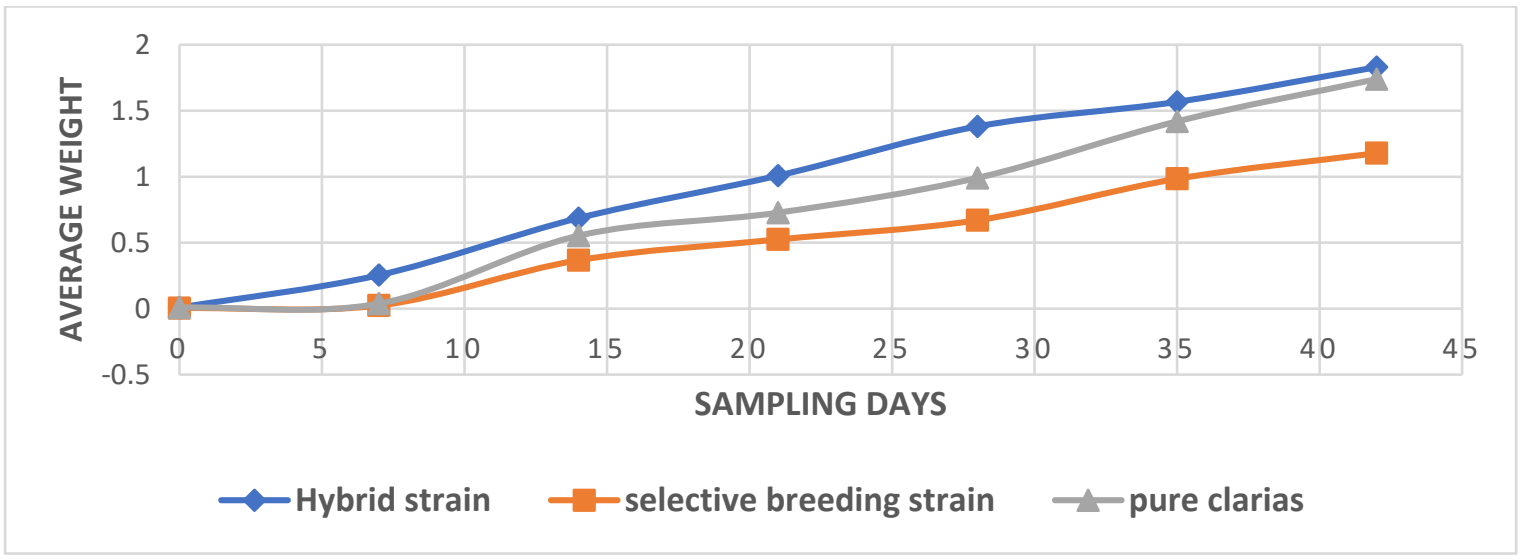

Figure 1: Shows the changes in mean weight of the three strains over the period of the study.

The Figure 1 shows trend of mean body weight of the three Clarias gariepinus strains reared in the concrete tanks over the period of six weeks. It shows that hybrid strain has a high mean weight followed by the pure Clarias gariepinus. The selective breeding strain had a least mean weight of the period of experiment 
Feed conversion ratio (FCR) of the three strains of Clarias gariepinus over the period of the study.

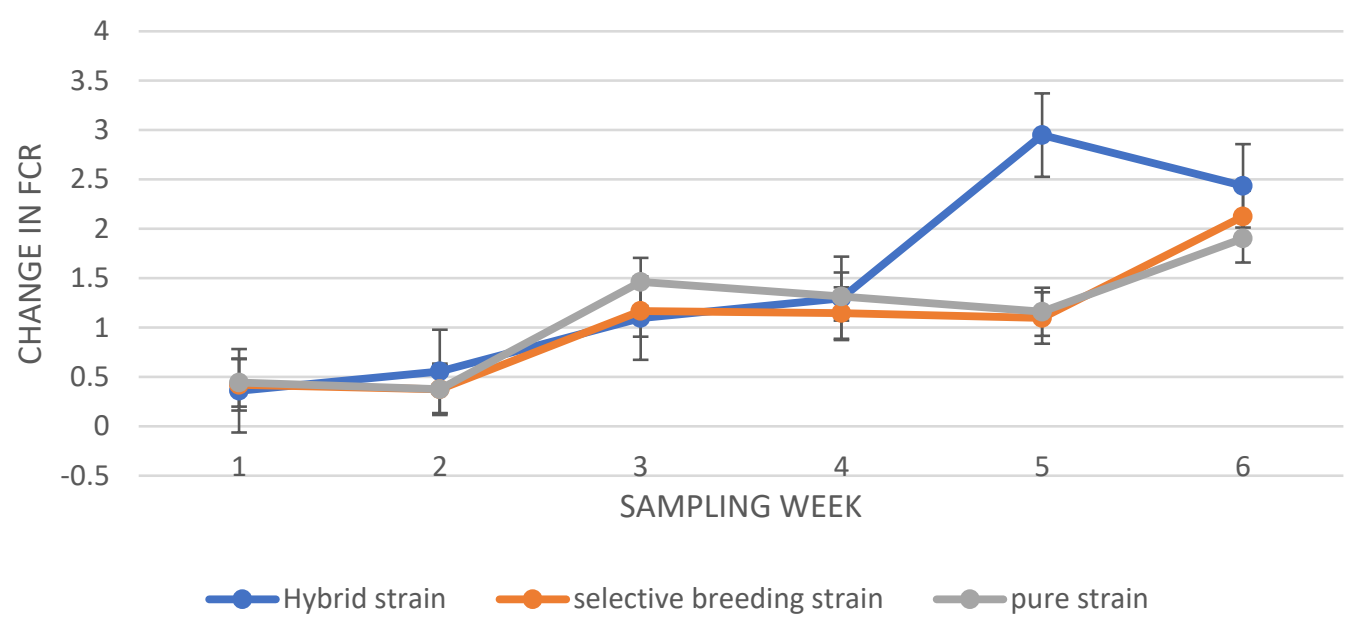

Figure 2: Shows the changes in the values of FCR for hybrid, selective breeding and pure strain of Clarias gariepinus. The trends shows that the change in FCR for hybrid is higher than the other two. This is followed by that of selective breeding strain with the pure Clarias coming the last.

Correlation between the average final weight of fish and the FRC of the three strains of Clarias gariepinus

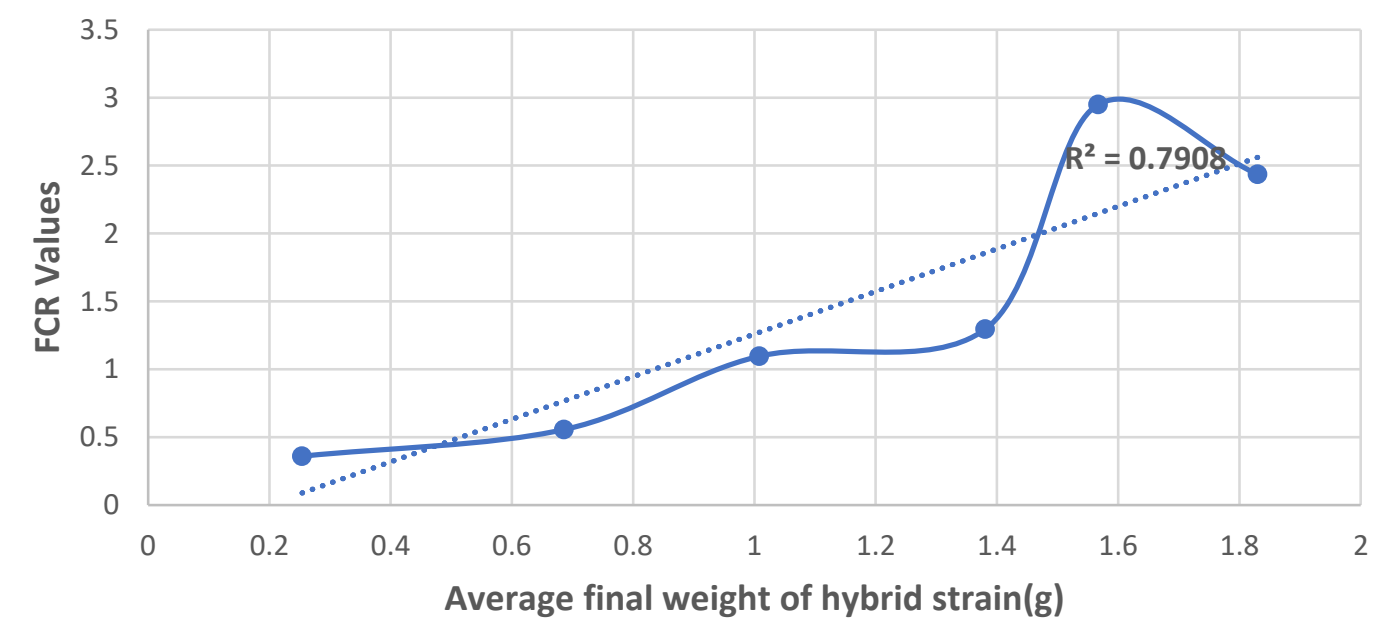

Figure 3: Shows the feed conversion ratio as a function of weight of hybrid strain of Clarias gariepinus 
African Journal of Agriculture and Food Science

ISSN: 2689-5331

Volume 4, Issue 4, 2021 (pp. 1-10)

www.abjournals.org

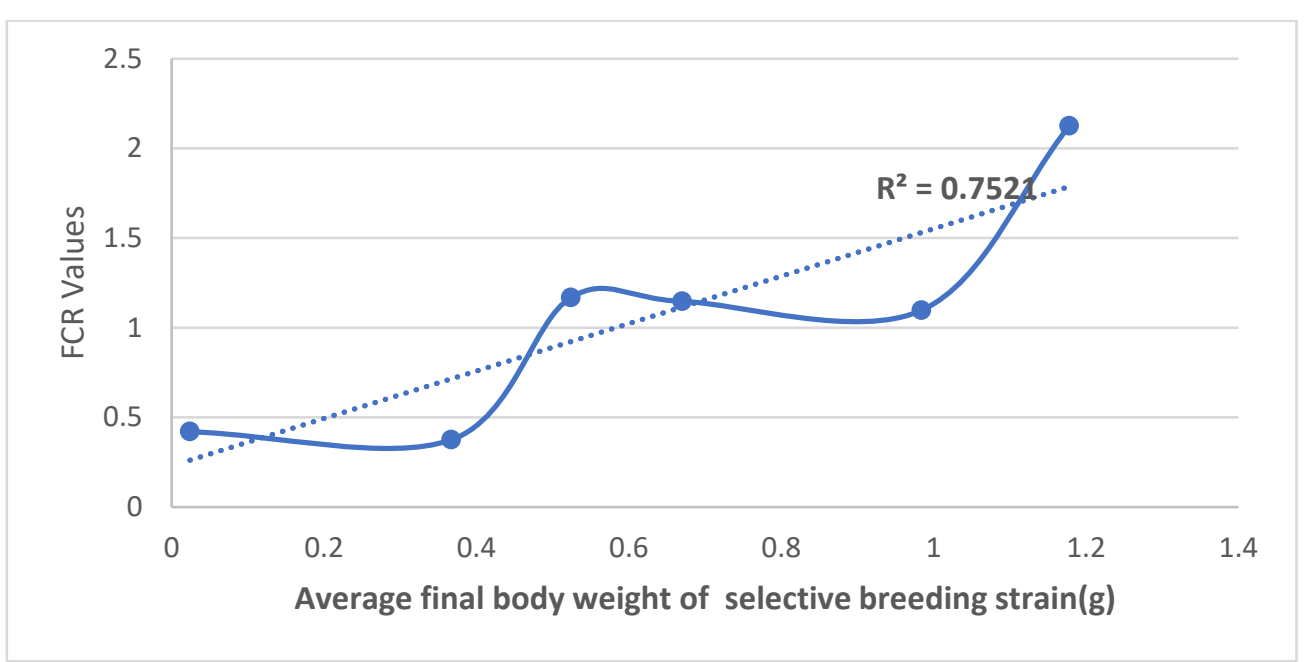

Figure 4: Shows the feed conversion ratio as a function of fish a function weight of fish weight of selective breeding strain

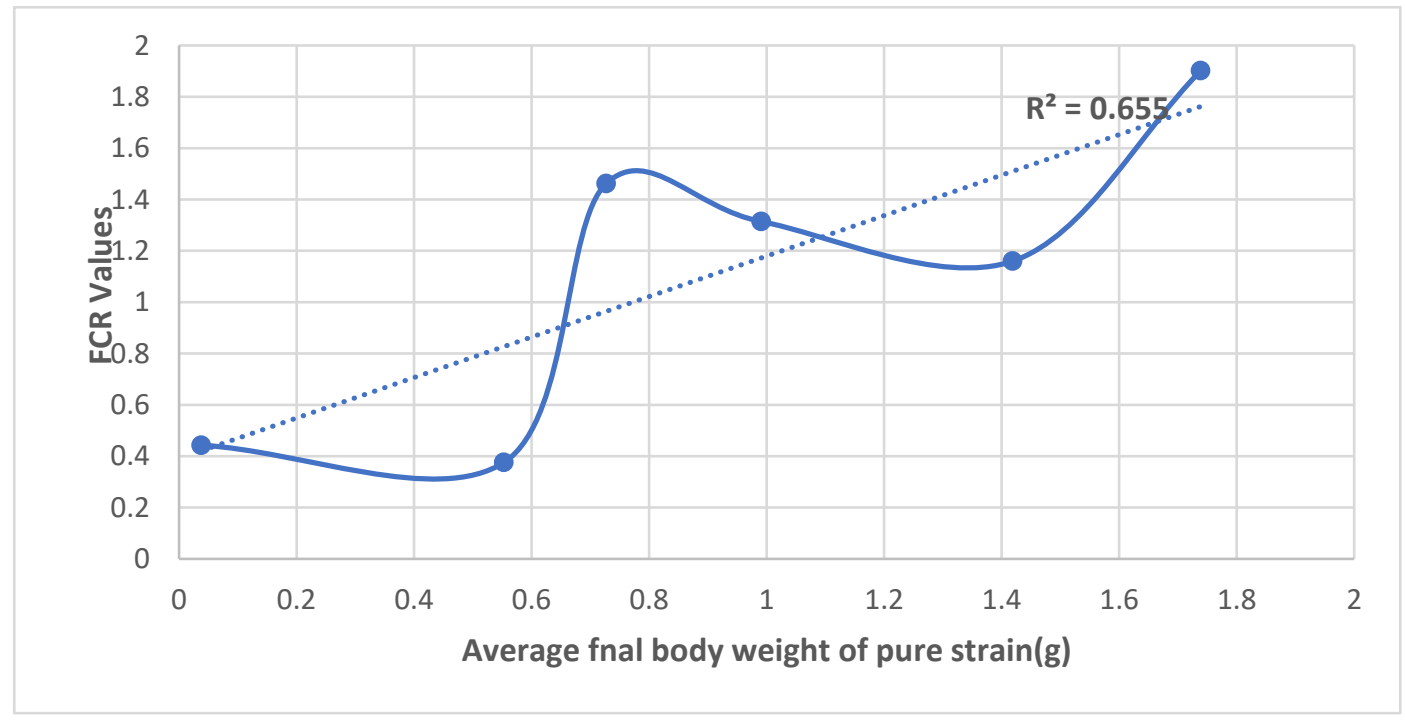

Figure 5: Shows the feed conversion ratio as a function of fish weight of Pure Clarias gariepinus over the period of the experiment 


\section{Physio-chemical Characteristics water of Treatments in the tanks}

Table 2: Shows the physio-chemical properties of water for the three treatments. The water parameters include temperature, dissolved oxygen and $\mathrm{pH}$.

\begin{tabular}{llll}
\hline Parameter & $\begin{array}{l}\text { Hybrid } \\
\text { strain }\end{array}$ & selective breeding strain & Pure strain \\
\hline Temp $\left({ }^{\mathbf{0}} \mathbf{C}\right)$ & $20.7 \pm 0.07$ & $20.3 \pm 0.07$ & $20.4 \pm 0.06$ \\
\hline D0(mg/l) & $5.5 \pm 0.14$ & $5.68 \pm 0.17$ & $5.88 \pm 0.09$ \\
\hline pH & $7.8 \pm 0.11$ & $7.63 \pm 0.14$ & $7.88 \pm 0.17$
\end{tabular}

The water quality parameters were not significantly different from each other among the treatments $(\mathrm{p}=0.9)$. The recorded temperature ranged from $20.3^{0} \mathrm{C}$ to $20.7^{0} \mathrm{C}$. The $\mathrm{pH}$ level recorded in all the treatments stood at the ranges from $7.63^{\circ} \mathrm{C}$ to $7.8^{\circ} \mathrm{C}$. The levels of dissolved oxygen ranged from $5.5 \mathrm{mg} / \mathrm{l}$ to $5.88 \mathrm{mg} / \mathrm{l}$. The physio-chemical properties obtained in the experiment were within the tolerable values for catfish production.

\section{DISCUSSION OF RESULTS}

\section{Growth Performance and Survival of the three strains of Clarias gariepinus}

The assessment of the growth performance indicates that the results (figure 1) the weight change of fish overtime was higher in the hybrid strain followed by the pure Clarias gariepinus. The selective breeding strain came last. Furthermore, the results (Table 1) on Mean weight gain ranged from $1.174 \mathrm{~g}, 1.731 \mathrm{~g}$ and $1.822 \mathrm{~g}$. The specific growth rate of the fish indicate that it ranged from $4.53 \mathrm{~g}, 12.81 \mathrm{~g}$ and $12.93 \mathrm{~g}$. The selective breeding strain reported the slowest SGR. This was followed by the pure Clarias gariepinus. The hybrid strain of the Clarias gariepinus reported to have a higher SGR. This high mean weight gain and SGR values in the hybrid strain as compared to others shows that the hybrid strain is more efficient in utilizing the food given and converting it into the biomass. This efficiency may be due to the fact the hybrids tend to have the genetic gains in terms of traits that enable them to perform well as compared to their wild strain (Mbamba, 2016). Hybridization is the production of progeny of parents from different lines, strains and species. It is one of the genetic improvements in aquaculture industry which has been recognized as a tool for stock improvement and management purposes (Owodeinde et al 2012). On the other hand, the reasons accounting to the poor performance of the selective breeding strain may be due to the fact that the selection may result into passing on some undesirable trait that may result in poor performance of the fish. This is in line with study by Green \& Rawles (2010) comparing the Channel x blue hybrid catfish with the wild strain where it was found that the hybrid catfish grew more quickly from because it consumed a higher percentage of its body weight at each feeding by with. The results (Table 1) shows that the survival rate ranged from $66.66 \%, 70 \%$ and $80 \%$. The selective breeding strain had high survival rate as compared to the other two. The lower survival rate in pure and hybrid strain may be due to cannibalism. Catfish are usually cannibalistic, which means that as they grow, they will feed on each other. They eat the tails of one another. The degree of cannibalism 
in catfishes is said to be determined by the availability of food. When the feed supply is insufficient to meet the needs of the fish, the catfish begin to eat one another (Al-Hafedh, Yousef \& Ali,2004).

\section{Feed conversion ratio (FCR) of the three strains of Clarias gariepinus over the period of the study}

Lower FCR values show the efficiency in converting the feed into body mass (Robinson \& Menghe,2010). A lower FCR means that fish utilized the feed better. If the FCR is higher than the optimum level it implies that feed is being wasted (Alyshbaev, 2013). Therefore, FCR for the three stains shows that there is no significant difference between the treatments $(P=0.65)$. The pure strain had a lower FCR followed by the hybrid strain. The selective breeding strain had the higher value of FCR. The FCR for pure Clarias gariepinus indicates that it was more efficient in retaining the protein and energy from the feed and converting the feed to body mass as compared to the other two, among the treatments in terms.

\section{Correlation between the weight of fish and the FRC of the three strains of Clarias gariepinus}

According to (Bluman, 2009), the values of $\mathrm{R}$ indicate the strength correlation. Results in figure 3 , shows that hybrid strain had the high value of coefficient of determination $\left(r^{2}=0.79\right)$ This shows that the hybrid strain has a high significant relation between FCR and the body weight. On the same wavelength figure 4 and 5 shows that the selective breeding strain and pure strain had the coefficient of determination of $\left(r^{2}=0.75\right)$ and $\left(r^{2}=0.66\right)$ respectively. All the graphs show that the FCR and the wight gain of the fish are correlated. This finding is in tandem with the results of the study conducted by Robinson \& Menghe (2010) on channel catfish which demonstrated that FCR increases as fish size increases and that FCR and fish size are highly correlated.

\section{Physio-chemical Characteristics of water of Treatments in the tanks}

The water quality parameters were within the good limits. There was no significant difference in the water quality parameters(p>0.05). The requirement for dissolved oxygen is that its concentrations should not fall below 4-5ppm. However, the catfish are reported to survive in extreme environments with low levels of dissolved oxygen. This can be explained by the resistance level of the fish to survive even under extreme dissolved oxygen levels of $0.23 \mathrm{ppm}$ since they are breathers (Van Weerd 1995). According to Toko et al 2006, Clarias gariepinus is reported to have normal growth rate even at oxygen concentration between $0.9 \mathrm{ppm}$ to 1.2 ppm. This explains why there is no significant difference in growth between the treatments. The range of temperature in the study is reported to be within the tolerable range though the metabolic fluctuation may occur (Yeamni et al. 2007). The $\mathrm{pH}$ values (Table 2) were also within the acceptable limits. Usually, higher $\mathrm{pH}$ is reported to lower liver activity. For example, in a study done by Jacobsen (2005) showed that a low and undesirable $\mathrm{pH}$ for fish growth lowers the liver activity and during their study, $\mathrm{pH}$ levels became undesirable for fish survival in aquaculture ponds (Tucker et al 2008), hence lowering the liver's activity. The optimal growth rate obtained at $\mathrm{pH}$ range of 7 to 9 were also shown in other studies (Tucker et al 2008). 


\section{CONCLUSION}

In conclusion, this study represents a step-in understanding of the growth performance of three strains of Clarias gariepinus. The results indicate that the hybrid strain has shown a higher performance as compared to the selective breeding strain and the pure strain when grown under captivity in the concrete tanks. The hybrid has been followed by the pure strain with the selective coming last. We hereby recommend to farmers to opt for hybrid strain of Clarias gariepinus for rearing in concrete tanks.

\section{REFERENCE}

Aibek alyshbaev (2013). Feeding level effect on the growth of rainbow trout (onchorynchus mykiss) fingerlings. University of Eastern Finland,

Al-Hafedh, Yousef \& Ali, SA. (2004). Effects offeeding on survival, cannibalism, growth and feed conversion of African catfish, Clarias gariepinus (Burchell) in concrete tanks. Journal of Applied Ichthyology. 20. 225 - 227. 10.1111/j.1439-0426.2004.00544. x.

Andrew, T.G., Weyl, O.L.F., Andrew, M., 2003. Aquaculture Masterplan Development in Malawi - Socio-Economic Survey Report. Aquaculture Development in Malawi, Report. Japanese International C o-operation Agency (JICA).

Bluman, A. G. (2009). Elementary statistics: A step by step approach. New York: McGrawHill Higher Education.

Breuil, Christophe. Grima, Damien (2014). Baseline Report Malawi. Smart Fish Programme of the Indian Ocean Commission, Fisheries Management FAO. component, Ebene, Mauritius. $29 \mathrm{pp}$

Chirwa, B. (2008). Status Of Catfish Production in Malawi. National Aquaculture Center. Department of Fisheries, Domasi, Malawi

FAO (2005). Fishery Country Profile - Republic of Malawi. Food and Agriculture Organization, Rome.

Green., B.W \& Steven D Rawles (2010). Comparative growth and yield of channel catfish and channelblue hybrid catfish fed a full or restricted ration. Aquaculture Research, $2010,41, \mathrm{e} 109 \wedge$ e119.

Jacobsen O. J. (2005). Does Low Environmental pH Influence Hepatic Growth in Fish?

Litvinoff E. (2009). Aquaculture in Lake Malawi: An analysis of the social, economic and environmental sustainability. Ecological Aquaculture Studies and reviews. University of Rhode Island, Kingston. 6 pp.

Malawi Government. (2016). National Fisheries and Aquaculture Policy.

Mbamba D., Mzengereza K., Singini W., Kapute F. and Zidana H., (2016). Comparison of Spawning Rate Between Wild and Improved Strain of Oreochromis shiranus (Boulenger, 1897), International Journal of Marine Science, 6(31): 1-7.

Owodeinde, F.G. Fakoya K.A and Anetekhai, M.A. (2012). Growth Performance of Hybrid Catfish (Clarias gariepinusx Heterobranchus bidorsalis) in Earthen Ponds. Asian Journal of Biological Sciences, 5:192-200.

Ponzoni, R.W. and N.H. Nguyen (2008). Proceedings of a Workshop on the Development of a Genetic Improvement Program for African catfish Clarias gariepinus. World Fish Centre. Conference Proceedings Number 1889. The World Fish Centre, Penang, Malaysia. $130 \mathrm{p}$. 
Robinson, Edwin \& Menghe, L. (2010). Channel Catfish, Ictalurus punctatus, Size and Feed Conversion Ratio. Journal of the World Aquaculture Society.41.829-833. 10.1111/j.1749-7345.2010.00426. x.

Russell AJM, Grötz PA, Kriesemer SK and Pemsl DE. (2008). Recommendation Domains for Pond Aquaculture. Country Case Study: Development and Status of Freshwater Aquaculture in Malawi. World Fish Centre Studies and Reviews No. 1869. The WorldFish Centre, Penang, Malaysia. 52.

Toko I., Fiogbe E. D., Koukpode B. and Kestemont P. (2006). Rearing of African catfish (Clarias gariepinus) and vundu catfish (Heterobranchus longifilis) in traditional fish ponds (whedos): Effect of stocking density on growth, production and body composition Aquaculture.

Tucker C. S. and D'Abramo L. R. (2008). Managing High pH in Freshwater Ponds. Southern Region Aquaculture Centre.

Van Weerd J. H., (1995). Nutrition and growth in Clarias species - a review. Aquat. Living Resource.

Yeamni Hossan, Saleha Jasmine and Abu Hanif Md Ibrahim (2007). A Preliminary Observation on Water Quality and Planktons of an Earthen Fish Pond in Bangladesh: Recommendation for Future Studies. Pakistan Journal of Biological Science. 10(6):868873. 